and macrophages, and which is associated with coagulation and bacterial infiltration of the injured tissue. Finally, there is an endocrine or late phase characterised by proliferation with endothelium and vascular wall modelling (angiogenesis), which, in the case of healing, involves tissular regeneration or wound healing by scar formation [2-4].

Therefore, in an early or nervous phase, the nutrition of the injured tissue would be produced by diffusion (oedema), a mechanism with low energetic requirement that does not require oxygen (ischemia) or that is not correctly used (synthesis of reactive oxygen species (ROS)). Products derived from the degradation of macromolecules by the ROS action can constitute substrates that reach the cells by diffusion. In the intermediate or immune phase, the nutrition could be mediated by the inflammatory cells because both the neutrophils, as well as the macrophages, have a large capacity for intracellular (phagocytosis of debris) and extracellular (release of enzymes) digestion [5, 6]. Complex proteins, such as enzymes and debris, can be important sources of fermentation [7]. These inflammatory cells respond with respiratory burst and release high concentrations of superoxide anion radical, hydroxyl radical, hypochlorus acid, hypobromite and hydrogen peroxide [1]. The lymphatic circulation could predominate in these phases of the inflammation in detriment of the blood circulation. Finally, in the late or endocrine phase, blood circulation is involved in the nutrition [5, 6]. Angiogenesis makes it possible to acquire a capillary network that is specialised in supplying oxygen and substrates to cells, which, in turn, use them through oxidative metabolism [6, 8], thus producing regeneration. However, the wounds heal by scar formation, a process in which the fibroblasts, due to their phenotypic plasticity [9], could become intermediary cells of the epithelial nutrition. The deficient capacity of the fibroblasts for this trophic function could explain the defective quality of the epithelium obtained.

Phases that are similar to the above-mentioned ones are commonly described in airway asthmatic inflammation [1,9]. In this way, reactive oxygen species hyperproduction, whether by revascularisation or by reactive oxygen species release by the inflammatory cells during the respiratory burst, could represent primitive trophic mechanisms, which are used by the injured tissue when the use of oxygen by oxidative phosphorylation is not possible. More useful energy (adenosine triphosphate) can be generated through this latter pathway and it is a more elaborated trophic mechanism.

\section{M-A. Aller*, J-L. Arias" ${ }^{\#}$ J. Arias* \\ *Surgery Chair, Surgery I Dept, Complutense University of Madrid, and "Psychobiology Dept, Psychology School, Uni- versity of Oviedo, Principality of Asturias, Spain.}

\section{References}

1. Wood LG, Gibson PG, Garg ML. Biomarkers of lipid peroxidation, airway inflammation and asthma. Eur Respir $J$ 2003; 21: 177-186.

2. Lorente L, Aller MA, Arias JL, Arias J. Complement: a cascade with neuro, immune and endocrine functions (letter). Transplantation 1996; 61: 1424-1425.

3. Lorente L, Aller MA, Arias JL, Alonso MS, Arias J. Clinical biology of nitric oxide (letter). Br J Surg 1996; 83: 10101011.

4. Aller MA, Arias JL, Lorente L, Nava MP, Durán HJ, Arias J. Neuro-immune-endocrine functional system and vascular pathology. Med Hypotheses 2001; 57: 561-569.

5. Lawrence WT. Physiology of the acute wound. Clin Plastic Surg 1998; 25: 321-340.

6. Monaco JL, Lawrence T. Acute wound healing. An overview. Clin Plastic Surg 2003; 30: 1-12.

7. Bengmark S. Pre-, pro- and symbiotics. Curr Opin Clin Nutrition Metab Care 2001; 4: 571-579.

8. Lingen MW. Role of leukocytes and endothelial cells in the development of angiogenesis in inflammation and wound healing. Arch Pathol Lab Med 2001; 125: 67-71.

9. Davies DE, Wicks J, Powell RM, Puddicombe SM, Holgate ST. Airway remodelling in asthma: new insights. J Allergy Clin Immunol 2003; 111: 215-215.

\title{
Adrenal suppression from high-dose inhaled fluticasone propionate in children with asthma
}

\section{To the Editor:}

We read with great interest the paper by Sim et al. [1] who observed adrenal suppression from high-dose inhaled fluticasone propionate (FP) in children with asthma. As adrenal inhibition has also been reported to occur with moderate doses of inhaled FP [2], we recently addressed the question whether low-dose (100 $\mu \mathrm{g}$ twice daily) FP could be associated with impaired adrenal function. For this purpose, 25 children (16 males/9 females) aged 2-12 yrs (mean \pm SD $5.78 \pm 3.1 \mathrm{yrs}$ ) were recruited. All children were affected by moderate asthma and treated with inhaled FP with spacer device for up to 3 months. Early morning cortisol and adrenocorticotrophic hormone $(\mathrm{ACTH})$ levels were determined at the beginning and at the end of the treatment period, after inhalatory therapy had been withdrawn for $\geqslant 24 \mathrm{~h}$. Serum cortisol and ACTH levels were measured by commercially available radioimmunoassay. Data were analysed by paired t-testing and Pearson correlation coefficient. Cortisol levels were significantly higher at the beginning of the treatment period $\left(449 \pm 158.3 \mathrm{nmol} \cdot \mathrm{L}^{-1}\right)$ when compared to the end of therapy (377.4 $\left.\pm 110.8 \mathrm{nmol} \cdot \mathrm{L}^{-1} ; \mathrm{p}=0.01\right)$; one patient presented cortisol levels compatible with complete adrenal suppression $\left(131.8 \mathrm{nmol} \cdot \mathrm{L}^{-1}\right)$ This was associated with significantly higher levels of ACTH at the end of therapy (36.5 \pm 4.3 versus $\left.28.3 \pm 9.5 \mathrm{pg} \cdot \mathrm{mL}^{-1} ; \mathrm{p}=0.01\right)$. No correlation could be found between age and adrenal dysfunction $(\mathrm{p}=0.09)$. The combination of low early morning cortisol levels and high ACTH levels at the end of FP therapy, having withdrawn the inhaled corticosteroid therapy for at $24 \mathrm{~h}$, is highly suspicious of adrenal suppression during treatment with prompt, but partially recovery of the pituitary-adrenal axis once therapy is stopped. Despite the large extent of the adrenal dysfunction, none of the children showed clinical symptoms of adrenal 
suppression. However, this phenomena might lead to decreased adrenal response to stress and infections, and should therefore not be underestimated [3].

In conclusion, with reference to the important message of Sim et al. [1] on a significant interference with the pituitaryadrenal axis of high-dose fluticasone propionate, clinicians should be aware of the possibility of adrenal impairment even with low-dose fluticasone propionate, as this has important implications not only for the management of intercurrent illnesses but also on the way of tapering the inhalatory therapy as previously suggested [4].

A. Mohn, M. Verini, R. Mele, C. De Leonardis, F. Chiarelli Dept of Paediatrics, University of Chieti, Chieti, Italy

\section{References}

1. Sim D, Griffiths A, Armstrong D, Clarke C, Rodda C, Freezer N. Adrenal suppression from high-dose inhaled fluticasone proprionate in children with asthma. Eur Resp $J$ 2003; 21: 633-636.

2. Wong JY, Zacharin MR, Hocking N, Robinson PJ. Growth and adrenal suppression in asthmatic children on moderate to high doses of fluticasone propionate. $J$ Paediatr Child Health 2002; 38: 59-62.

3. Taylor AV, Laoprasert N, Zimmermann D, Sachs MI. Adrenal suppression secondary to inhaled fluticasone propionate. Ann Allergy Asthma Immunol 1999; 83: 6870.

4. Crowley S. Inhaled glucocorticoids and adrenal function: an update. Paediatr Resp Rev 2003; 4: 153-161. 